\title{
Replacement value of cottonseed meal for soybean meal in broiler chicken diets with or without microbial enzymes
}

\author{
Medani Eldow Abdallh $h^{1,2^{*}}$, Sosthene Musigwa ${ }^{1}$, Emmanuel Uchenna Ahiwe ${ }^{1,3}$, \\ Edwin Peter Chang'a ${ }^{1,4}$, Mohamed Al-Qahtani ${ }^{1}$, Momenuzzaman Bhuiyan ${ }^{1}$ \\ and Paul Ade $\mathrm{lj}^{1,5}$ \\ ${ }^{1}$ Department of Animal Science, School of Environmental and Rural Sciences, University of New \\ England, Armidale, NSW 2351, Australia \\ ${ }^{2}$ University of Khartoum, Department of Poultry Production, Khartoum 13314, Sudan \\ ${ }^{3}$ Department of Animal Science and Technology, Federal University of Technology, Owerri, Imo State, \\ 1526, Nigeria \\ ${ }^{4}$ Tanzania Livestock Research Institute, P.O. Box 352, TALIRI-Mabuki, Mwanza, Tanzania \\ ${ }^{5}$ College of Agriculture, Fisheries \& Forestry, Fiji National University, P.O. Box 1544 Nausori, Fiji
}

Received: Jul 21, 2019

Revised: Nov 13, 2019

Accepted: Nov 13, 2019

*Corresponding author

Medani Eldow Abdallh

Department of Animal Science, School of Environmental and Rural Sciences,

University of New England, Armidale,

NSW 2351, Australia.

Tel: +61469615773

E-mail: medani38@gmail.com

Copyright $\odot 2020$ Korean Society of

Animal Sciences and Technology.

This is an Open Access article

distributed under the terms of the

Creative Commons Attribution

Non-Commercial License (http://

creativecommons.org/licenses/by-

$\mathrm{nc} / 4.0 /$ ) which permits unrestricted

non-commercial use, distribution, and

reproduction in any medium, provided

the original work is properly cited.

ORCID

Medani Eldow Abdallh

https://orcid.org/0000-0002-8419-5057

Sosthene Musigwa

https://orcid.org/0000-0002-1089-0786

Emmanuel Uchenna Ahiwe

https://orcid org/0000-0001-9862-7503

Edwin Peter Chang'a

https://orcid.org/0000-0002-8978-6921

Mohamed Al-Qahtani

https://orcid.org/0000-0001-7317-1319

\section{Abstract}

A $4 \times 2$ factorial feeding trial was designed to investigate the effect of replacing soybean meal (SBM) with cottonseed meal (CSM) in wheat/sorghum/SBM-based diets fed with or without microbial enzymes in diets on the performance, visceral organ development and digestibility of nutrients of broiler chickens. Four graded levels of CSM - none (0\%), low (4\%, $8 \%$, and $12 \%)$, medium $(5 \%, 10 \%$, and $15 \%)$, and high $(6 \%, 12 \%$, and $18 \%$ ) of complete diets in starter, grower and finisher, respectively were fed with or without $100 \mathrm{mg} / \mathrm{kg}$ of xylanase and $\beta$-glucanase blend. Eight isocaloric and isonitrogenous diets were formulated using least-cost method to meet the nutrient specifications of Ross 308 male broilers. Each treatment was randomly assigned to 6 replicates (10 birds per replicate). There were CSM-enzyme interactions $(p<0.05)$ on feed intake (FI) and weight gain (WG) in the starter phase. Enzyme supplementation improved $(p<0.05)$ feed conversion ratio $(F C R)$ in the grower and finisher phases, and increased WG in growing and finishing birds. CSM inclusion reduced $(p<0.05)$ the weight of gizzard and proventriculus in starter chicks, while these organs were bigger $(p<0.05)$ in the grower phase. The test ingredient decreased $(p<0.05)$ small intestinal weight in starter and grower birds. The CSM increased the absolute weight of thighs $(p<0.05)$ while breast meat was increased ( $p$ $<0.01$ ) by enzyme addition. Starch digestibility was improved $(p<0.01)$ by enzyme inclusion and decreased $(p<0.01)$ by CSM. Enzyme supplementation improved $(p<0.05)$ the ileal digestibility of gross energy and protein. The results demonstrate that CSM can substitute up to $90 \%$ SBM in broiler chicken diets without compromising performance, and the nutritive value of CSM-containing diets can effectively be improved by enzyme supplementation.

Keywords: Broilers performance, Cottonseed meal, Microbial enzymes, Nutrient digestibility, Soybean meal 
Momenuzzaman Bhuiyan

https://orcid.org/0000-0002-6538-4047

Paul Ade lij

https://orcid.org/0000-0002-6981-6281

Competing interests

No potential conflict of interest relevant to

this article was reported.

Funding sources

This work was supported by Feedworks Pty Ltd, Australia and the University of New England.

Acknowledgements

The authors gratefully acknowledge the

Feedworks Pty Ltd, Australia for their

financial support, and the University of New

England.

Availability of data and material Upon reasonable request, the datasets of this study can be available from the corresponding author.

Authors' contributions

Conceptualization: lji PA, Abdallh ME.

Data curation: Abdallh ME, Musigwa S, Ahiwe EU, Chang'a EP, Al-Qahtani M, Bhuiyan M.

Formal analysis: Abdallh ME.

Methodology: Abdallh M, lji PA

Software: Abdallh ME.

Validation: Abdallh M, lji PA.

Investigation: Abdallh ME.

Writing - original draft: Abdallh ME, Musigwa S

Writing - review \& editing: Abdallh ME, Musigwa S, Ahiwe EU, Chang'a EP, AlQahtani M, Bhuiyan M, lji PA.

Ethics approval and consent to participate This article does not require IRB/IACUC approval but was approved by the University of New England Animal Ethics Committee (AEC15-084).

\section{INTRODUCTION}

The price of conventional protein sources such as soybean meal (SBM), which is the predominant plant protein source used in the poultry industry, keeps increasing. This may result in loss in volume of poultry production due to the cost of production or formulation of poor diets. Therefore, cheaper alternative protein ingredients are desperately needed in poultry feed formulation that can maintain feed quality and bird performances [1,2]. For this purpose, cottonseed meal (CSM) has extensively been investigated and it has been shown to be a potential source of protein and a substitute for costly SBM in poultry diets [1-3]. This oilseed residue is highly rich in protein, with values between $41 \%$ and $44 \%$ crude protein (CP), depending on the degree of dehulling before oil extraction [4]. On the other hand, using this ingredient in poultry feeds presents a number of challenges and limitations, including high fibre content, presence of gossypol, and unbalanced amino acids, particularly a low content of lysine [1,4]. The amount of gossypol in CSM has been reported to vary from $0.03 \%$ to $0.2 \%[2,5]$. The high fibre content and gossypol presence in CSM have deleterious effects on feed intake (FI) and growth performance [6]. A number of reports have demonstrated different ways to optimize the use of CSM in poultry diets, including plant breeding, proper processing [2], supplementation with lysine [7] and other feed additives. Furthermore, special combination of dietary ingredients and feed additives can improve bird performance [8].

Exogenous enzymes are feed additives which can improve CSM utilization by poultry. One of the factors that can impede nutrient digestibility and reduce dietary protein utilization is the presence of non-starch polysaccharides (NSP). According to Perez-Maldonado and Australian Egg Corporation Limited [9] the total content of all NSP fractions of commonly used Australian CSM is reported to be as follows ( $\mathrm{g} / \mathrm{kg}$ dry matter): arabinose (37-44), xylose (31-33), mannose (3-4), rhamnose (3-4), fucose (1-1.5), galactose (10-11), and glucose (40-46). It is well established that supplementing NSP-degrading enzymes, such as $\beta$-glucanase, xylanase and pectinase in fibrous diets can potentially lower the intestinal content viscosity and improve digestibility $[10,11]$. Numerous reports have investigated the effect of using xylanase with or without $\beta$-glucanase in wheatbased diets on nutrient utilization and broiler performances [10-12]. However, the information on the impact of incorporating a $\beta$-glucanase and xylanase cocktail in diets containing CSM as a major source of protein for broiler is still limited. Therefore, the aim of this study was to investigate the effect of graded replacement of SBM by CSM with or without a $\beta$-glucanase and xylanase enzyme blend on broiler chicken growth performance and nutrient digestibility.

The overall objective of this study was to evaluate CSM as an alternative and cost-effective protein ingredient to SBM without compromising broiler performance. To achieve this, two specific objectives were developed: (a) To investigate the effect of CSM levels in broiler diets on nutrient digestibility and bird performance; and (b) To evaluate the response of birds to CSM-containing diets supplemented with a composite microbial enzyme product with xylanase and $\beta$-glucanase activities. Therefore, based on the above objectives, the following hypotheses were formulated: (a) The level of CSM inclusion in diets can influence the nutritive value of the diets; and (b) The nutritive value of CSM-containing diets can be improved by microbial enzyme supplementation.

\section{MATERIALS AND METHODS}

\section{Dietary treatments}

Four wheat/sorghum/soybean-based diets were formulated using the least-cost method to meet the nutrient specifications for Ross 308 broiler chicks Aviagen [13]. The diets contained different levels of CSM as follows: control (0\%) in all growing phases (starter, grower, and finisher), low (4\%, 8\%, 
and $12 \%)$, medium $(5 \%, 10 \%$, and $15 \%)$ and high $(6 \%, 12 \%$, and $18 \%)$ respectively. Each diet was fed as such or supplemented with composite microbial enzymes (Axtra XB) at $100 \mathrm{mg} / \mathrm{kg}$ of diet. Axtra XB (Danisco Animal Nutrition, UK) is a blend of two microbial enzymes, xylanase and $\beta$ -glucanase, providing 250 units of $\beta$-glucanase and 2,500 units of xylanase per $\mathrm{kg}$ of the formulated feeds. In addition, an indigestible marker, titanium dioxide $\left(\mathrm{TiO}_{2}\right)$, was incorporated in the grower diets at a rate of $5 \mathrm{~g} / \mathrm{kg}$ of diet, in order to assess nutrient digestibility. The starter chicks (from one to 10 days) were fed with crumbled feed, while the grower (from 11 to 24 days) and finisher (from 25 to 35 days) chicks were fed whole pellet diets. Diets were pelleted at $65^{\circ} \mathrm{C}$. Tables 1 and 2 show the ingredient composition of the diets used in the trial and the calculated nutrient composition of these diets respectively, while Table 3 shows the analyzed nutrient composition of the tested CSM, which were locally produced and purchased (Riverina, Milton, QLD, Australia).

\section{Experimental design and bird husbandry}

The trial was a $4 \times 2$ factorial arrangement in which birds were randomly allocated into eight treatments. Each treatment was replicated six times, with 10 chickens per replicate, which made a total of 480 birds. One-day old male Ross 308 chicks were purchased from a commercial hatchery, (Baiada, Tamworth NSW, Australia), with average initial weight of $41.1 \pm 0.8 \mathrm{~g} /$ chicks. The cages were placed in a climate controlled room. Light was provided for $24 \mathrm{~h}$ on the first day and then reduced to $18 \mathrm{~h}$ per day from the second day until the end of the experiment. The room temperature was also set as follows: $33^{\circ} \mathrm{C}$ on day one, then gradually decreased to $24^{\circ} \mathrm{C}$ from day 18 to the end of the feeding trial. Each cage was provided with a feeding trough and automated water system with two drinking nipples. The birds had ad libitum access to drinking water and feed. Bird observations were done on a regular basis to monitor health status, feed and water supplies, and environmental conditions. The experiment was ended at 35 days of age.

\section{Sample collection and assessment}

Feeds and birds were weighed at a cage basis on 0,10,24, and 35 days of age to determine the FI, WG, and feed conversion ratio (FCR). In addition, when there was a death, the dead bird, the remaining birds and feeds were weighed to correct FI and FCR. The visceral organs (small intestine, liver, gizzard and proventriculus, bursa and spleen) were collected from the birds killed on day 10 and 24 weighed and recorded. The relative weight of these organs was calculated as $\mathrm{g} / 100 \mathrm{~g}$ of body weight. To determine apparent nutrient digestibility in the ileum, diets and digesta samples were collected. Diet samples were collected in plastic bags directly from the feed mill after pelleting and cooling, ground and kept in plastic containers for nutrient analysis. On the 24th day of the trial, three birds were randomly selected from each replicate, weighed and euthanized by cervical dislocation to collect digesta samples. The entire gastrointestinal tract (GIT) was exposed and the ileum, which is the small intestinal portion extending from the vitelline (Merkel's) diverticulum to a point about $40 \mathrm{~mm}$ above the ileo-caecal junction, was cut and its contents were then flushed into a plastic container, frozen and freeze dried. Lyophilized ileal digesta were then ground using a coffee grinder and kept in air-tight containers at $4^{\circ} \mathrm{C}$ for further analysis.

To determine the carcass yield, on day 35 , two chickens were chosen from each cage, weighed, electrically stunned and euthanized using the cervical dislocation technique. The bird was scalded for $30 \mathrm{sec}$ in hot water (approximately $63^{\circ} \mathrm{C}$ ), and their feathers were plucked out in a batch defeatherer after which the carcass was eviscerated. The entire breast meat (pectoralis minor and pectoralis major), wings, thighs, and drumsticks (bones included) were separated from the carcass and their weight was recorded. The weight of these carcass parts was expressed as $\mathrm{g} / \mathrm{kg}$ of bird live weight. The remaining carcass parts and feeds were disposed of according to the local regulations. 


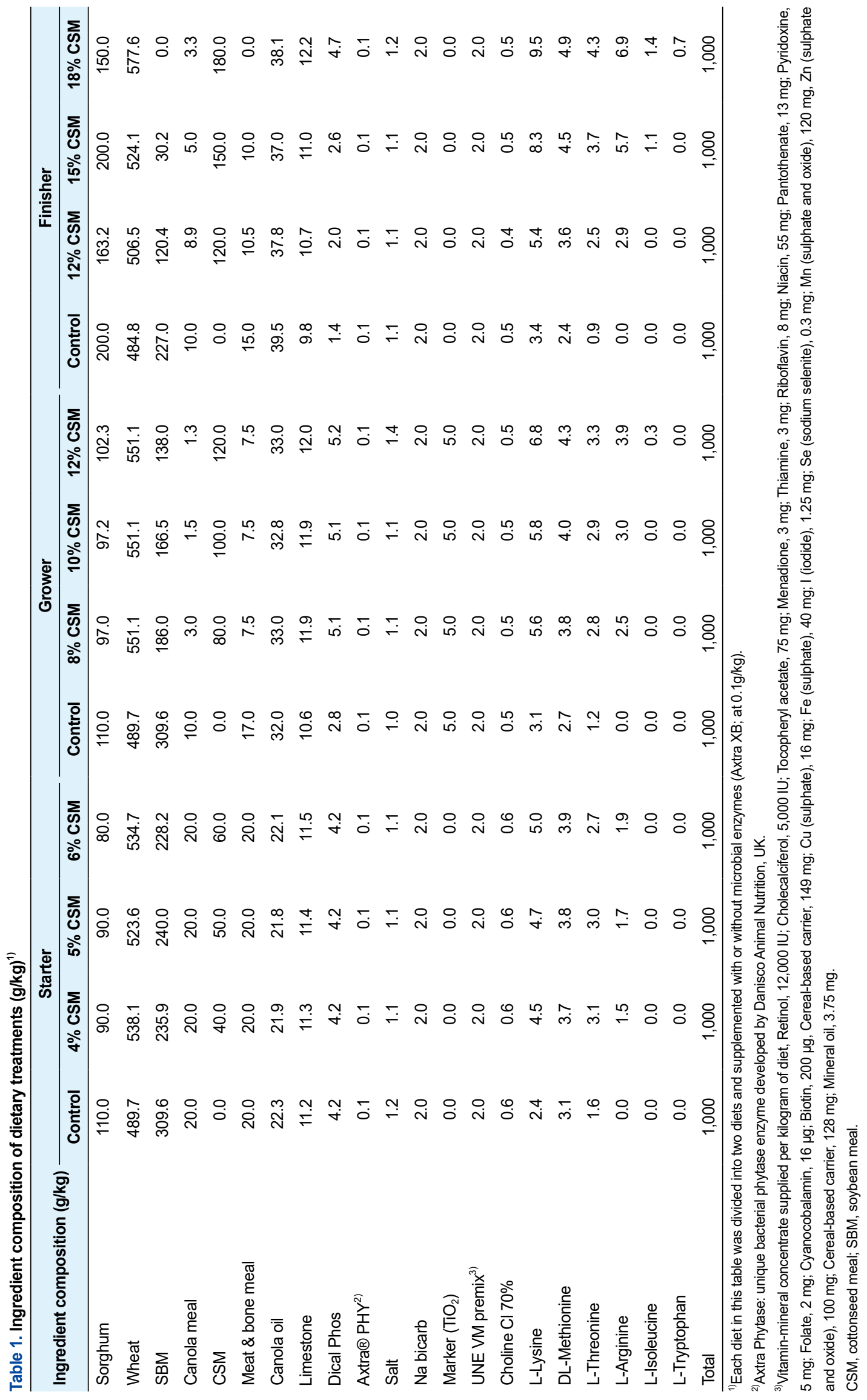




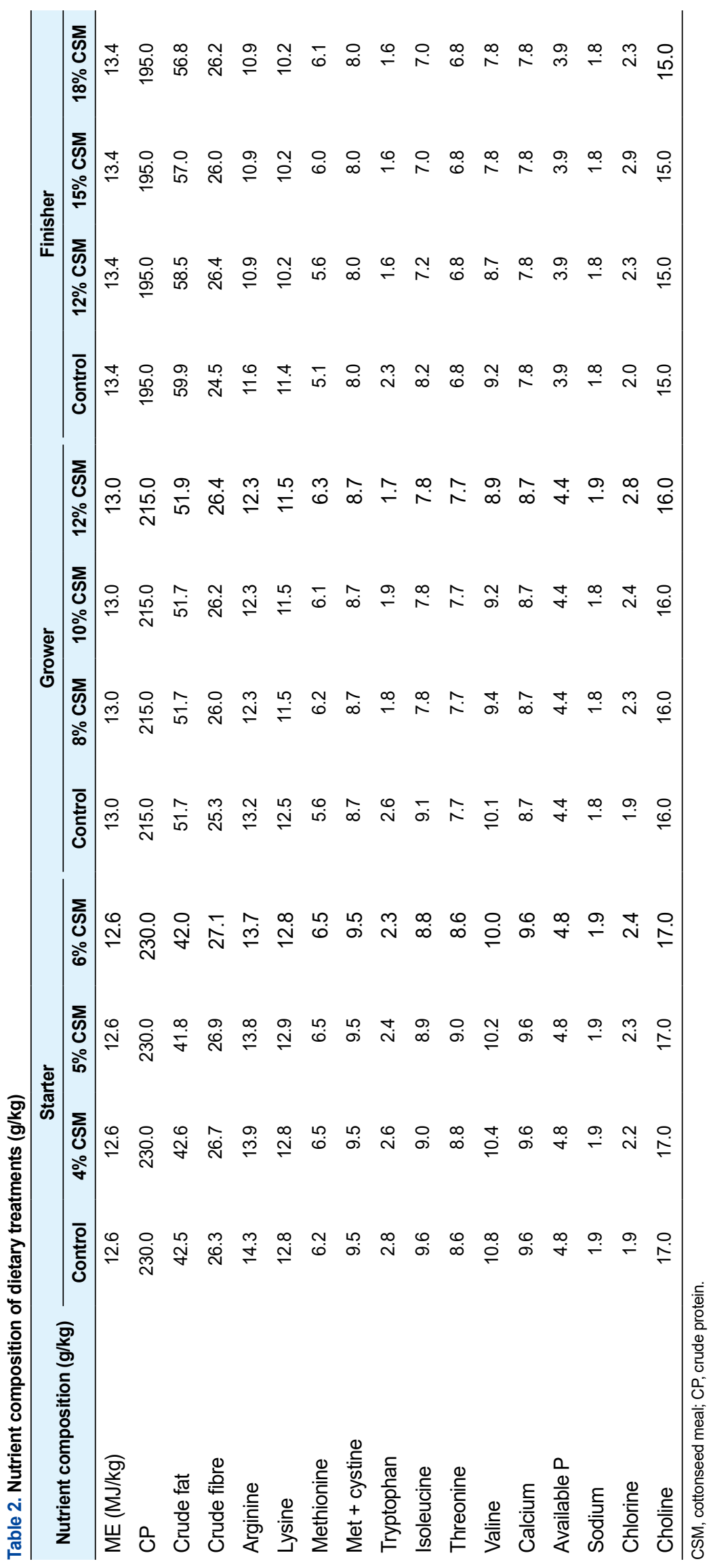


Table 3. Analyzed nutrient composition of the tested cottonseed meal

\begin{tabular}{|c|c|}
\hline Nutrient & Value \\
\hline ME (MJ/kg) & 9.7 \\
\hline Crude protein (\%) & 45.1 \\
\hline Crude fat (\%) & 1.7 \\
\hline Crude fibre (\%) & 8.6 \\
\hline Ash (\%) & 6.8 \\
\hline \multicolumn{2}{|l|}{ Indispensable amino acids (g/kg) } \\
\hline Arginine & 46.7 \\
\hline Lysine & 21 \\
\hline Methionine & 6.9 \\
\hline Threonine & 14.6 \\
\hline Tryptophan & 5 \\
\hline Valine & 21.5 \\
\hline Histidine & 13 \\
\hline Leucine & 26.7 \\
\hline Isoleucine & 14.4 \\
\hline Phenylalanine & 24.8 \\
\hline \multicolumn{2}{|l|}{ Minerals $(\mathrm{g} / \mathrm{kg})$} \\
\hline Calcium & 1.8 \\
\hline Total phosphorus & 9.1 \\
\hline Sodium & 0.45 \\
\hline Potassium & 1.3 \\
\hline
\end{tabular}

\section{Nutrients analyses and digestibility calculations}

The concentration of $\mathrm{TiO}_{2}$ in the diets and ileal digesta was measured according to the colorimetric procedure of Short et al. [14], using about $0.1 \mathrm{~g}$ of digesta and $0.2 \mathrm{~g}$ of the diet samples. Ground diet samples were oven-dried at $105^{\circ} \mathrm{C}$ for $24 \mathrm{~h}$ to determine DM content of experimental diets using a forced air convection oven (Qualtex Universal Series 2000, Watson Victor Ltd, Perth, Australia). The DM content of the ileal digesta samples was obtained directly after freeze-drying (Martin Christ freeze dryer, Germany) at $-50^{\circ} \mathrm{C}$ for at least $72 \mathrm{~h}$. The nitrogen content of ileal digesta and diet samples was measured using the Dumas combustion technique, following the method described by Sweeney [15], through direct electronic reading on a LECO ${ }^{\circledR}$ FP-2000 automatic nitrogen analyzer (Leco Corporation, St. Joseph, MI, USA). The obtained nitrogen results were then converted to $\mathrm{CP}$ content, using a factor of 6.25 . Around $0.5 \mathrm{~g}$ of finely ground $(0.5 \mathrm{~mm})$ diet and ileal digesta samples were weighed in metallic crucibles to determine gross energy (GE), using an IKA ${ }^{\circledR}$-WERKE bomb calorimeter (C7000, GMBH \& Co., Staufen, Germany), and the GE value of samples measured as $\mathrm{MJ} / \mathrm{kg}$, was read from the calorimeter digital system. The method developed by McCleary et al. [16] was followed to assess the total starch content of diets and ileal digesta. The Megazyme total starch assay kitAA/AMG (Megazyme International Ireland Limited, Bray, Co. Wicklow, Ireland) was used for total starch analysis. Absorbance was read at $510 \mathrm{~nm}$ on a spectrophotometer (Varian Cary 50 Bio UV - Visible Spectrophotometer Mulgrave, Victoria, Australia) against milli-Q water.

The index method proposed by Moughan and Marlies Leenaars [17] and reviewed by Kong and Adeola [18] with titanium dioxide as an index compound was used to determine nutrient digestibility. The following equation was used to calculate apparent ileal digestibility of nutrients: 


$$
\text { AIDN }=1-\frac{\mathrm{Ti}_{\text {Diet }} \times \mathrm{N}_{\text {Digesta }}}{\mathrm{TiO}_{2 \text { Digesta }} \times \mathrm{N}_{\text {Diet }}}
$$

where, AIDN is the coefficient of apparent ileal digestibility of nutrients, $\mathrm{N}_{\text {Digesta }}$ is the nutrient concentration in digesta $(\mathrm{g} / \mathrm{kg}), \mathrm{TiO}_{2}$ Digesta is the titanium concentration in digesta $(\mathrm{g} / \mathrm{kg}), \mathrm{N}_{\text {Diet }}$ is nutrient concentration in diets $(\mathrm{g} / \mathrm{kg})$ and $\mathrm{TiO}_{2}$ Diet is the titanium concentration in feeds $(\mathrm{g} / \mathrm{kg})$.

\section{Statistical analysis}

Broiler chicken's growth, visceral organs development, meat yield and nutrient digestibility data were statistically analyzed according to $4 \times 2$ factorial arrangement. The obtained data were subjected to analysis of variance (ANOVA) in the procedures of general linear model of Minitab statistical software, version 17 [19]. Fisher's least significant difference (LSD) method for multiple comparisons was used to separate significant differences between mean values at $p \leq 0.05$ level of probability.

\section{Animal ethics}

The experimental design and methodology were approved by the Animal Ethics Committee of the University of New England, Australia under approval number AEC15-084. All husbandry and management procedures used were in accordance with The Code of Practice for the Use of Animals for Scientific Purposes was issued by the Australian Bureau of Animal Health.

\section{RESULTS}

\section{Effect of CSM and microbial enzyme (Axtra XB) on gross responses}

The FI, WG, and FCR in response to the four CSM levels in diets supplemented with or without Axtra XB enzyme are summarized in Table 4 . In starter broilers (1-10 days), there was an interaction between the enzyme and CSM on FI $(p<0.028)$ and WG $(p<0.036)$. In the starter and grower phases (1-24 days) and entire cycle (1-35 days), FI did not vary $(p>0.05)$ between dietary treatments. The FCR was improved $(p<0.023)$ by CSM in the starter phase mostly in lower and medium CSM diets, and in the grower $(p<0.045)$ phase, particularly in chickens fed with the maximal level of CSM. Supplementation with Axtra XB enzyme increased WG in the grower $(p<$ $0.037)$ and finisher $(p<0.036)$ phases. Enzyme addition significantly improved FCR in the grower $(p<0.008)$ and finisher $(p<0.017)$ phases. There was no interaction between enzyme and CSM for gross responses over 1-24 and 1-35 days.

\section{Effect of CSM and Axtra XB enzyme on visceral organ weights}

Incorporation of CSM in diets decreased the weight of the small intestine $(p<0.008)$ and the combined weight of gizzard plus proventriculus $(p<0.048)$ in starter chicks (Table 5). In grower birds, CSM contributed increased $(p<0.029)$ the weight of gizzard plus proventriculus with the highest weight recorded in the birds fed medium-CSM diet. The test ingredient decreased $(p<0.013)$ the weight of the small intestine in growing chickens except for those fed the medium level of CSM. There was no treatment effect $(p>0.05)$ on the weight of the other visceral organs at 10 or 24 days of age.

\section{Effect of CSM and Axtra XB enzyme on meat yield}

There was no interaction between CSM levels and Axtra XB enzyme on the weight of carcass parts. The enzyme supplement significantly increased $(p<0.007)$ the absolute weight of breast meat (Table 6). Diets containing CSM also resulted in an increase in thigh weight both in absolute $(p<0.024)$ 


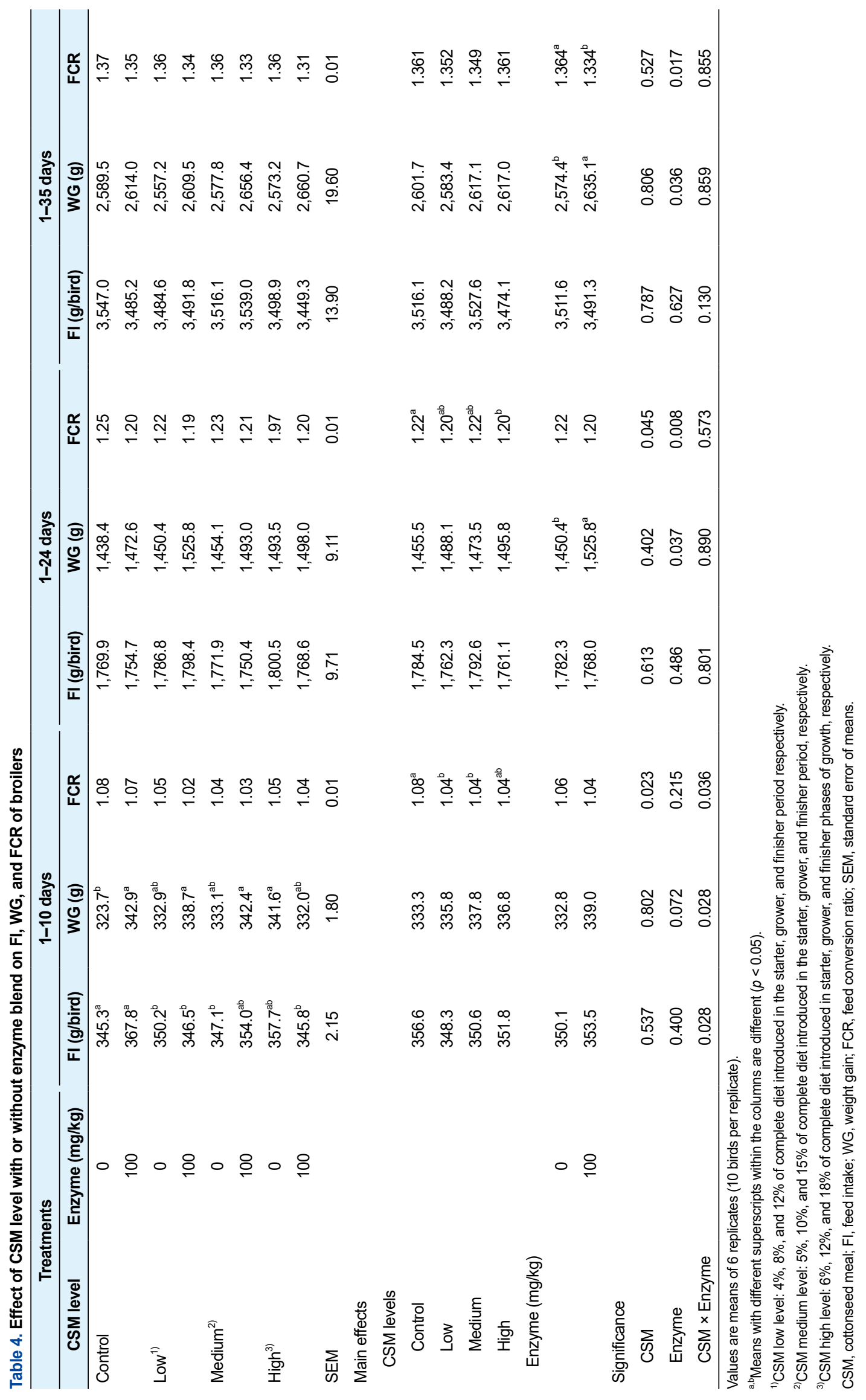




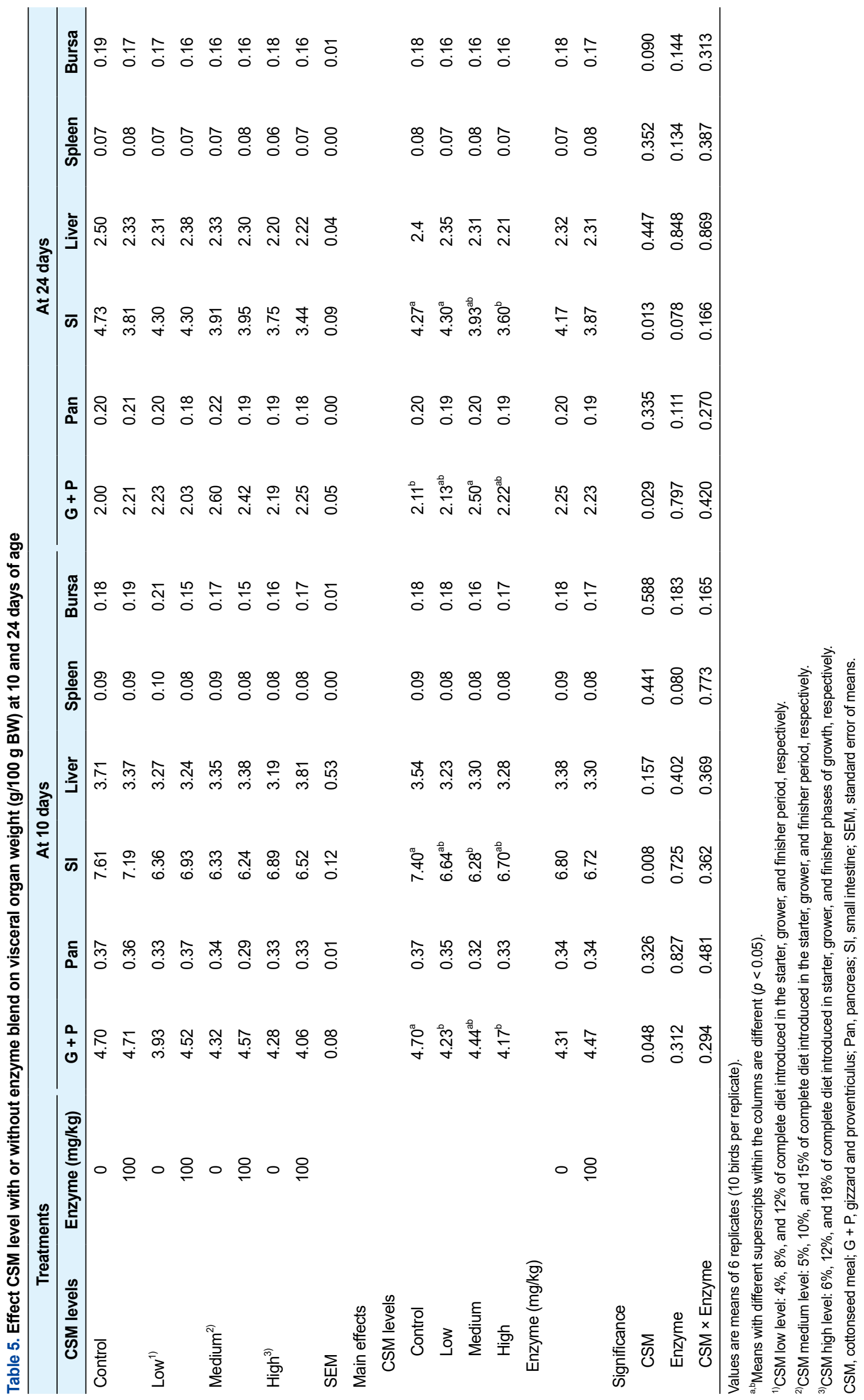


Table 6. Effect of CSM level with or without enzyme blend on meat yield1 in absolute ( $\mathrm{g}$ of carcass wt) and relative weight (g/100 of carcass wt) at 35 days of age

\begin{tabular}{|c|c|c|c|c|c|c|c|c|c|c|}
\hline \multicolumn{2}{|c|}{ Treatment } & \multicolumn{5}{|c|}{ Absolute weight } & \multicolumn{4}{|c|}{ Relative to live weight } \\
\hline CSM levels & Enzyme (mg/kg) & $\begin{array}{c}\text { Dressing } \\
(\%)\end{array}$ & Breast & Thighs & Wings & $\begin{array}{l}\text { Drum- } \\
\text { sticks }\end{array}$ & Breast & Thighs & Wings & $\begin{array}{l}\text { Drum- } \\
\text { sticks }\end{array}$ \\
\hline \multirow[t]{2}{*}{ Control } & 0 & 76.0 & 537.9 & 258.2 & 198.3 & 236.5 & 202.2 & 97.2 & 74.8 & 88.9 \\
\hline & 100 & 76.8 & 562.7 & 260.6 & 199.9 & 242.2 & 206.9 & 95.8 & 73.5 & 89.0 \\
\hline \multirow[t]{2}{*}{ Low2 } & 0 & 76.4 & 528.5 & 258.8 & 187.4 & 233.4 & 202.4 & 99.0 & 71.8 & 89.3 \\
\hline & 100 & 76.9 & 587.1 & 278.7 & 208.9 & 257.0 & 210.4 & 99.8 & 74.8 & 91.9 \\
\hline \multirow[t]{2}{*}{ Medium3 } & 0 & 76.5 & 538.7 & 275.9 & 186.9 & 241.7 & 203.2 & 103.9 & 70.5 & 91.1 \\
\hline & 100 & 77.2 & 552.1 & 290.9 & 189.1 & 250.8 & 203.2 & 103.3 & 71.7 & 90.1 \\
\hline \multirow[t]{2}{*}{ High4 } & 0 & 76.8 & 537.9 & 283.7 & 193.5 & 263.4 & 195.2 & 103.2 & 70.3 & 95.7 \\
\hline & 100 & 77.0 & 562.7 & 283.8 & 198.8 & 250.1 & 203.7 & 102.3 & 71.7 & 90.3 \\
\hline SEM & & 0.18 & 5.58 & 3.41 & 2.20 & 2.87 & 0.15 & 0.09 & 0.05 & 0.06 \\
\hline \multicolumn{11}{|l|}{ Main effects } \\
\hline \multicolumn{11}{|l|}{ CSM Levels } \\
\hline Control & & 76.4 & 550.3 & $259.4 b$ & 199.3 & 239.3 & 204.6 & $96.5^{b}$ & 74.1 & 90 \\
\hline Low & & 76.6 & 557.8 & $268.8 \mathrm{ab}$ & 198.2 & 245.2 & 206.4 & $99.4^{\mathrm{ab}}$ & 73.3 & 90.6 \\
\hline Medium & & 76.8 & 545.4 & 283.4ab & 188 & 246.2 & 203.2 & $103.6^{\mathrm{a}}$ & 71.1 & 90.6 \\
\hline High & & 76.9 & 550.3 & $283.7 a$ & 195.9 & 256.8 & 199.4 & $102.7^{\mathrm{a}}$ & 71.0 & 93.0 \\
\hline \multicolumn{11}{|l|}{ Enzyme (mg/kg) } \\
\hline & 0 & 76.4 & $535.8^{b}$ & 269.1 & 191.7 & 243.7 & $200.8^{b}$ & 100.8 & 71.8 & 91.3 \\
\hline & 100 & 76.9 & $566.2^{\mathrm{a}}$ & 278.5 & 199.1 & 250.0 & $206.0^{\mathrm{a}}$ & 100.3 & 72.9 & 91.3 \\
\hline \multicolumn{11}{|l|}{ Significance } \\
\hline CSM & & 0.756 & 0.875 & 0.024 & 0.234 & 0.165 & 0.404 & 0.015 & 0.068 & 0.122 \\
\hline Enzyme & & 0.126 & 0.007 & 0.149 & 0.084 & 0.252 & 0.083 & 0.745 & 0.271 & 0.440 \\
\hline CSM× Enzyme & & 0.944 & 0.481 & 0.630 & 0.289 & 0.136 & 0.722 & 0.975 & 0.476 & 0.125 \\
\hline
\end{tabular}

Values are means of 6 replicates (10 birds per replicate).

a,b Means with different superscripts within the columns are different $(p<0.05)$.

${ }^{1)}$ Meat yield refers to breast, thighs, wings, and drumsticks.

${ }^{2)} \mathrm{CSM}$ low level: $4 \%, 8 \%$, and $12 \%$ of complete diet introduced in the starter, grower, and finisher period, respectively.

${ }^{3)} \mathrm{CSM}$ medium level: $5 \%, 10 \%$, and $15 \%$ of complete diet introduced in the starter, grower, and finisher period, respectively.

${ }^{4)} \mathrm{CSM}$ high level: $6 \%, 12 \%$, and $18 \%$ of complete diet introduced in starter, grower, and finisher phases of growth, respectively

SEM, standard error of means; CSM, cottonseed meal.

and relative $(p<0.015)$ terms. Apart from these carcass parts, there was no treatment effect $(p>0.05)$ observed in other body parts (meat) yield.

\section{Apparent ileal digestibility of nutrients}

The enzyme increased apparent ileal digestibility of $\mathrm{CP}(p<0.030)$, gross energy $(p<0.014)$ and starch $(p<0.008)$ in the ileum (Table 7). However, the apparent ileal starch digestibility was reduced $(p<0.010)$ by increasing CSM level in the diet, with the lowest starch digestibility noted in chickens fed the diets containing a high level of CSM. There was no effect $(p>0.05)$ of CSM on $\mathrm{CP}$ or gross energy digestibility.

\section{DISCUSSION}

\section{Gross responses}

Apart from the CSM-enzyme interaction observed on FI, feed consumption did not differ be- 
Table 7. Apparent lleal digestibility of nutrients in response to different CSM levels with or without the enzyme blend

\begin{tabular}{|c|c|c|c|c|}
\hline CSM levels & Enzyme & Crude protein & Gross energy & Starch \\
\hline \multirow[t]{2}{*}{ Control } & 0 & 0.81 & 0.70 & 0.95 \\
\hline & 100 & 0.81 & 0.72 & 0.98 \\
\hline \multirow[t]{2}{*}{ Low $^{1)}$} & 0 & 0.78 & 0.66 & 0.95 \\
\hline & 100 & 0.82 & 0.71 & 0.97 \\
\hline \multirow[t]{2}{*}{ Medium $^{2)}$} & 0 & 0.80 & 0.70 & 0.95 \\
\hline & 100 & 0.80 & 0.71 & 0.96 \\
\hline \multirow[t]{2}{*}{$\mathrm{High}^{3)}$} & 0 & 0.79 & 0.66 & 0.93 \\
\hline & 100 & 0.82 & 0.69 & 0.96 \\
\hline SEM & & 0.00 & 0.01 & 0.00 \\
\hline \multicolumn{5}{|l|}{ Main effects } \\
\hline \multicolumn{5}{|l|}{ CSM levels } \\
\hline Control & & 0.81 & 0.70 & $0.97^{\mathrm{a}}$ \\
\hline Low & & 0.80 & 0.69 & $0.96^{\mathrm{ab}}$ \\
\hline Medium & & 0.80 & 0.70 & $0.95^{\mathrm{ab}}$ \\
\hline High & & 0.80 & 0.68 & $0.94^{b}$ \\
\hline \multicolumn{5}{|c|}{ Enzyme (mg/kg)) } \\
\hline & 0 & $0.80^{\mathrm{b}}$ & $0.68^{b}$ & $0.94^{b}$ \\
\hline & 100 & $0.81^{\mathrm{a}}$ & $0.71^{\mathrm{a}}$ & $0.97^{\mathrm{a}}$ \\
\hline \multicolumn{5}{|l|}{ Significance } \\
\hline CSM & & 0.729 & 0.231 & 0.010 \\
\hline Enzyme & & 0.030 & 0.014 & 0.008 \\
\hline CSM level $\times \mathrm{Er}$ & & 0.230 & 0.664 & 0.410 \\
\hline
\end{tabular}

Values are means of 6 replicates (10 birds per replicate).

${ }^{a, b}$ Means with different superscripts within the columns are different $(p<0.05)$

${ }^{1)} \mathrm{CSM}$ low level: $4 \%, 8 \%$, and $12 \%$ of complete diet introduced in the starter, grower, and finisher period, respectively.

${ }^{2)} \mathrm{CSM}$ medium level: $5 \%, 10 \%$, and $15 \%$ of complete diet introduced in the starter, grower, and finisher period, respectively.

${ }^{3)} \mathrm{CSM}$ high level: $6 \%, 12 \%$, and $18 \%$ of complete diet introduced in starter, grower, and finisher phases of growth,respectively.

SEM, standard error of the mean; CSM, cottonseed meal.

tween the dietary treatments and the control diet. This can be explained by the fact that, although CSM is high in fibre, the experimental diets were formulated in such a way that all nutrients were similar and balanced to meet the birds' nutrient requirements. This supports the results of a feeding trial conducted by Adeyemo and Longe [20] in which no specific FI pattern in meat chickens fed CSM-containing diets was found, although after the seventh week of their trial, differences between treatments means emerged. The enzyme interacted with CSM on WG response in starting birds and the values of this response were identical between birds fed CSM- and SBM-containing diets both in the growing and finishing phases. CSM can cause growth depression in chicks and this could, among other factors, be due to decreased amino acids digestibility, low lysine content and the presence of gossypol [21]. However, digestibility of amino acids, was improved in the present trial, which can counteract the gossypol effect and growth depression as stated by Henry et al. [22] and Nagalakshmi et al. [23]. These findings agree with the results obtained by Ojewola et al. [2] who reported that the WG of broilers fed CSM-containing diets was similar to that of birds fed SBM diet. However, this was not supported other work which recorded a significant differences in WG when CSM replaced SBM in broiler diets [20]. These authors demonstrated a similarity in gross response values among chickens fed diets in which soybean cake was replaced by cottonseed cake at $75 \%$ compared to those fed a control diet. They also stated that a complete replacement of 
SBM with CSM resulted in depressed growth performance. However, in the present trial, the replacement of SBM with CSM by even up to $90 \%$ (18\% CSM diet) did not severely affect the gross responses. Enzyme supplementation in grower and finisher diets increased the WG and this may be due to its contribution to the improvement in nutrient digestibility, as previously reported that supplementation wheat-based diets with $\beta$-glucanase increased broiler growth [24].

It has been stated that starting chick diets containing high levels of CSM may have a depressing effect on growth coupled with increased feed-to-gain ratios due to the presence of gossypol [2]. Also it was stated that CSM-containing feeds consumed by birds were not converted as effectively as SBM diets due to poor utilisation of amino acids from CSM [20]. However, in the present trial, no statistical difference was observed in finisher chicks because of CSM incorporation in their diets. Most importantly, this proteinaceous ingredient contributed to a reduction in FCR in the starter and grower phases. As mentioned earlier, the enzyme supplement lowered the FCR in grower and finisher birds. These improvements could have resulted from enhanced energy and protein digestibility, initiated by the inclusion of the test enzyme. Feed conversion ratio has been shown to decrease in birds provided with diets containing a $\beta$-glucanase and xylanase cocktail [12].

\section{Visceral organ weights}

In the grower birds, CSM increased the weight of the gizzard and proventriculus. It is well established that the increased content of fibre in a diet can increase the length and size of the GIT [25,26]. Adding indigestible materials, such as wood shavings, can tremendously increase the weight of gizzard [27]. Other studies have linked the fibre content in dietary ingredients, such as CSM with hypertrophy of the GIT, including the gizzard [28,29]. Although, the fibre content of the formulated diets in this feeding trial was similar to the standard recommended by Aviagen [13], but CSM fibre tends to be physically bulky [30]. In the present trial, the activity of the test enzyme on wheatsorghum-CSM diets decreased the small intestinal weight, but the effect was not significant. The earlier work of Brenes et al. [31] also found that the weights of visceral organs (liver, pancreas, small intestine and proventriculus) were not affected by wheat or xylanase. Nayefi et al. [29] observed an increased weight of the gizzard and the rest of the GIT in birds fed CSM-containing diets.

\section{Body parts (meat) yield}

The yield of carcass parts and dressing percentage were expressed in relation to unit liveweight ( $g$ / $\mathrm{kg}$ ) and also absolute weight. The outstanding differences between these carcass parts included increased absolute weight of breast meat mediated through enzyme incorporation. The thighs obtained from birds fed CSM diets were also heavier than chickens fed the control diets. The increased weight of carcass parts can be associated with the improved brirds growth, due to increased nutrient digestibility, especially CP and apparent metabolizable energy (AME). The weights of other carcass parts were similar to those of the control group. There are no previous data on the effect of using this kind of enzyme product in diets containing CSM on carcass parts (meat) yield. The eviscerated yield of meat chickens fed CSM-based diets with or without transgenic modification did not differ from the control group fed SBM diets [6].

\section{Apparent ileal digestibility of nutrients}

Batonon-Alavo et al. [32] reported that CSM inclusion in diets resulted in a decrease in apparent ileal energy digestibility, but in this trial, the gross energy digestibility was not affected by CSM. In addition, different studies have reported that phytase and xylanase supplementation improved AME [33,34]. However, a feeding trial conducted by Munyaka et al. [11] revealed that there was no influence of a xylanase and $\beta$-glucanase blend on the AME in meat chickens fed with wheat- 
and corn-based feeds. In the present feeding trial, starch digestibility decreased in birds fed high levels of CSM, with the lowest value observed in the group with the highest level of CSM. On the other hand, enzyme supplementation resulted in increased digestibility of starch. It has been found that incorporating a xylanase and $\beta$-glucanase blend in corn- and wheat-based diets resulted in increased starch digestibility, among other attributes [11]. This may be due to the role of $\beta$-glucanase and xylanase in reducing digesta viscosity caused by wheat arabinoxylans and pentosans and elimination of nutrient encapsulation of cell walls existing in many dietary ingredients, resulting in nutrient release $[11,12,35]$. The results from this feeding trial show that the graded substitution of SBM with CSM in broiler diets did not affect CP digestibility. Enzyme supplementation also resulted in increased apparent $\mathrm{CP}$ digestibility in the ileum by up to about $2 \%$. However, Mushtaq et al. [4] found no impact of adding a $\beta$-glucanase and xylanase cocktail to CSM-containing diets. The findings of the current study were similar to those obtained by Garcia et al. [26] who indicated that incorporating xylanase in wheat-based feeds improved ileal digestibility of dietary nutrients, including $\mathrm{CP}$.

\section{CONCLUSION}

The results provided by this feeding trial show that the overall performance of broilers fed CSM-containing diets supplemented with the test enzyme product is not inferior to that of birds fed the more expensive diets containing SBM. For the gross responses, CSM-fed birds showed almost the same responses as the control groups, particularly in the grower and finisher periods. In addition, enzyme supplementation improved different production parameters, such as nutrient digestibility, some gross responses (WG and FCR in grower and finisher phases) and breast meat yield. Therefore, it is evident from this trial that CSM can be a good alternative to SBM, while enzyme incorporation can further improve the quality of such diets by enhancing nutrient digestibility, especially energy. Further tests should investigate the performance of broilers fed diets containing CSM supplemented with other exogenous enzyme combinations, including sodium selenite, lipase and protease.

\section{REFERENCES}

1. Sterling KG, Costa EF, Henry MH, Pesti GM, Bakalli RI. Responses of broiler chickens to cottonseed-and soybean meal-based diets at several protein levels. Poult Sci. 2002;81:217-26.

2. Ojewola GS, Ukachukwu SN, Okulonye EI. Cottonseed meal as substitute for soyabean meal in broiler ration. Int J Poult Sci. 2006;5:360-4.

3. Njike MC. The effect of cottonseed meal (CSM) goundnut meal $(\mathrm{Gnm})$ mixture and protein levels in practical broiler diets. Nig J Anim Prod. 1977;4:81-4.

4. Mushtaq T, Sarwar M, Ahmad G, Mirza MA, Ahmad T, Athar M, et al. Influence of prepress solvent-extracted cottonseed meal supplemented with exogenous enzyme and digestible lysine on performance, digestibility, carcass and immunity responses of broiler chickens. J Anim Physiol Anim Nutr. 2009;93:253-62.

5. Jones LA. Special cottonseed products report. Foodstuffs. 1981;53:19-21.

6. Mandal AB, Elangovan AV, Shrivastav AK, Johri AK, Kaur S, Johri TS. Comparison of broiler chicken performance when fed diets containing meals of Bollgard II hybrid cotton containing Cry-X gene (Cry1Ac and Cry2Ab gene), parental line or commercial cotton. Br Poult Sci. 2004;45:657-63.

7. Packham RG, Royal AJE, Payne CG. Cottonseed meal in broiler diets. 1. The use of cotton- 
seed meal as a replacement for soya bean meal in broiler starter diets. Aust J Exp Agric Anim Husb. 1973;13:649-55.

8. Gamboa DA, Calhoun MC, Kuhlmann SW, Haq AU, Bailey CA. Use of expander cottonseed meal in broiler diets formulated on a digestible amino acid basis. Poult Sci. 2001;80:789-94.

9. Perez-Maldonado RA. Canola meal and cottonseed meal in broiler and layer diets. Hurstville: Australian Egg Corporation Limited; 2003. Publication No.: 03/10.

10. Silversides FG, Bedford MR. Effect of pelleting temperature on the recovery and efficacy of a xylanase enzyme in wheat-based diets. Poult Sci. 1999;78:1184-90.

11. Munyaka PM, Nandha NK, Kiarie E, Nyachoti CM, Khafipour E. Impact of combined $\beta$-glucanase and xylanase enzymes on growth performance, nutrients utilization and gut microbiota in broiler chickens fed corn or wheat-based diets. Poult Sci. 2016;95:528-40.

12. Esteve-Garcia E, Brufau J, Perez-Vendrell A, Miquel A, Duven K. Bioefficacy of enzyme preparations containing beta-glucanase and xylanase activities in broiler diets based on barley or wheat, in combination with flavomycin. Poult Sci. 1997;76:1728-37.

13. Aviagen. Ross broiler management handbook. Huntsville, AL: Aviagen; 2014.

14. Short FJ, Gorton P, Wiseman J, Boorman KN. Determination of titanium dioxide added as an inert marker in chicken digestibility studies. Anim Feed Sci Technol. 1996;59:215-21.

15. Sweeney RA. Generic combustion method for determination of crude protein in feeds: collaborative study.J Assoc Off Anal Chem. 1989;72:770-4.

16. McCleary BV, Solah V, Gibson TS. Quantitative measurement of total starch in cereal flours and products.J Cereal Sci. 1994;20:51-8.

17. Moughan PJ, Marlies Leenaars GS. Endogenous amino acid flow in the stomach and small intestine of the young growing pig.J Sci Food Agric. 1992;60:437-42.

18. Kong C, Adeola O. Evaluation of amino acid and energy utilization in feedstuff for swine and poultry diets. Asian-Australas J Anim Sci. 2014;27:917-25.

19. Minitab. MINITAB release 17: statistical software for windows. State College, PA: Minitab; 2014.

20. Adeyemo GO, Longe OG. Effects of graded levels of cottonseed cake on performance, haematological and carcass characteristics of broilers fed from day old to 8 weeks of age. Afr J Biotechnol. 2007;6:1064-71.

21. Azman MA, Yilmaz M. The growth performance of broiler chicks fed with diets containing cottonseed meal supplemented with lysine. Rev Med Vet. 2005;156:104-6.

22. Henry MH, Pesti GM, Bakalli R, Lee J, Toledo RT, Eitenmiller RR, et al. The performance of broiler chicks fed diets containing extruded cottonseed meal supplemented with lysine. Poult Sci. 2001;80:762-8.

23. Nagalakshmi D, Rao SVR, Panda AK, Sastry VRB. Cottonseed meal in poultry diets: a review. J Poult Sci. 2007;44:119-34.

24. Mathlouthi N, Ballet N, Larbier M. Influence of beta-glucanase supplementation on growth performances and digestive organs weights of broiler chickens fed corn, wheat and barley-based diet. Int J Poult Sci. 2011;10:157-9.

25. Viveros A, Brenes A, Pizarro M, Castano M. Effect of enzyme supplementation of a diet based on barley, and autoclave treatment, on apparent digestibility, growth performance and gut morphology of broilers. Anim Feed Sci Technol. 1994;48:237-51.

26. Garcia V, Catala P, Madrid J, Orengo J, Hernandez F. Polysaccharidase preparations added to a wheat-based diet: effects on performance and digestive parameters of broiler chickens held at three different locations. Br Poult Sci. 2008;49:164-75.

27. Hetland H, Svihus B, Choct M. Role of insoluble fiber on gizzard activity in layers. J Appl 
Poult Res. 2005;14:38-46.

28. Watkins SE, Skinner JT, Adams MH, Waldroup PW. An evaluation of low-gossypol cottonseed meal in diets for broiler chickens 1 . Effect of cottonseed meal level and lysine supplementation. J Appl Poult Res. 1993;2:221-6.

29. Nayefi M, Salari S, Sari M, Behgar M. Nutritional value of electron beam irradiated cottonseed meal in broiler chickens. J Anim Physiol Anim Nutr. 2016;100:643-8.

30. Watkins SE, Waldroup PW. Utilization of high protein cottonseed meal in broiler diets.J Appl Poult Res. 1995;4:310-8.

31. Brenes A, Smith M, Guenter W, Marquardt RR. Effect of enzyme supplementation on the performance and digestive tract size of broiler chickens fed wheat-and barley-based diets. Poult Sci. 1993;72:1731-9.

32. Batonon-Alavo DI, Bastianelli D, Lescoat P, Weber GM, Faruk MU. Simultaneous inclusion of sorghum and cottonseed meal or millet in broiler diets: effects on performance and nutrient digestibility. Animal. 2016;10:1118-28.

33. Ravindran V, Bryden WL. Evaluation of broiler diets containing graded levels of cottonseed meal and formulated on the basis of total or digestible amino acids. In: Proceedings of the Australian Poultry Science Symposium; 1999; Sydney.

34. Wu YB, Ravindran V, Thomas DG, Birtles MJ, Hendriks WH. Influence of phytase and xylanase, individually or in combination, on performance, apparent metabolisable energy, digestive tract measurements and gut morphology in broilers fed wheat-based diets containing adequate level of phosphorus. Br Poult Sci. 2004;45:76-84.

35. Veldman A, Vahl HA. Xylanase in broiler diets with differences in characteristics and content of wheat. Br Poult Sci. 1994;35:537-50. 